TIME AND DISTANCE:

REFLECTIONS ON LOCAL \& GLOBAL HISTORY FROM EAST AFRICA

By Richard Reid

READ 23 JUNE 2018

\title{
AT THE UNIVERSITY OF OXFORD
}

\begin{abstract}
This paper is concerned with East Africans' perceptions of the intersection between their own, highly charged and contested, local histories, and the global past, as well as their place in it. The two case studies on which the paper is based - Eritrea and Uganda - have much in common in terms of recent history, not least in their experience of prolonged violence, and thus taken together they elucidate distinctive characteristics. Yet they also illustrate broader phenomena. On one level, particular interpretations of local history - both the deeper, precolonial past, and the more recent, twentieth-century past - are utilised to critique the flow of global history, as well as the impositions of globalization, and to emphasize the bitter experience of marginality and lack of agency. At the same time, the global past - conceptualized as the evolution of an intrusive, imperialist, hypocritical global order imposed by foreigners, usually Western in provenance - is seen as omnipresent and pervasive, and thus the arguments made around marginality serve to remind us, paradoxically, how central these communities are (or should be) to the framing of global history.
\end{abstract}

\section{INTRODUCTION:}

\section{The Global(IZING) History OF AFRiCA}

This article is concerned with the intersection between the local and the global. The central issue under examination is local perceptions of global history, and specifically the intersection between East Africans' own highly contested local histories and the global past, as well as their place in it. But it is also the case that in both Uganda and Eritrea - the case studies on which the article is primarily based - 'global history' is often synonymous with 'globalization', a conscious or subconscious equivalence to which the researcher needs to be alert. Eritrea and Uganda have much in common in terms of recent history, not least in their experience of prolonged violence, and thus taken together they elucidate distinctive characteristics. Yet they also illustrate broader phenomena. On one level, particular interpretations of local history - both the deeper, precolonial past, and the more recent, twentieth-century past - are utilised to critique the flow of global history, as well as the impositions of globalization, and to emphasize the bitter experience of marginality and lack of agency. At the same 
time, the global past - conceptualized as the evolution of an intrusive, imperialist, hypocritical global order imposed by foreigners, usually Western in provenance - is seen as omnipresent and pervasive, and thus the arguments made around marginality serve to remind us, paradoxically, how central these communities are (or should be) to the framing of global history.

Be that as it may, as will be evident from what follows, the dominant perspective of local informants is that global history is the history of the world as shaped by those with power on a global stage - chiefly the European empires, the United States, China. Everyone else is marginal within such a model. The tyranny of the word-limit prevents a full elucidation of how this is far from being the only possible reading of what constitutes the practice of researching and writing global history; suffice to note that we find ourselves at a moment of reflection as to the trajectory and potential of the field. ${ }^{1}$ But local actors are far removed from current scholarly debates, although their concerns - the marginalizing forces of historic globalization; ideas about the role of 'tradition' in the face of modernity; the increasingly urgent need to protect and nurture local historical production - should certainly be made relevant to those debates. An older scholarship dealing with the tense interactions between the local and the global, dating back to the 1990s, remains germane in this respect. ${ }^{2}$

Nevertheless, the Africanist academy has not been immune from the seemingly inexorable rise of global history - far from it - and certainly not from the debates around globalization. ${ }^{3}$ In some ways, of course, historians of Africa have always been global historians, by the very nature of their work. Arguably, they have had greater cause to think about global and certainly transnational connections in ways that other, more mainstream 'area studies' scholars - including historians of Western Europe - have not. Core to the study of Africa's past has been the impact of imperialism and colonialism, or the transcontinental slave trades, themselves global historical phenomena. Yet in some respects the shift into global history on the part of African historians looks like something of a matriculation, or an elevation: I am thinking here of Tony Hopkins, Frederick Cooper, Crawford Young, and Patrick Manning, for example. ${ }^{4}$ The area-specialist research of their earlier careers - often dealing with the political and economic impacts of British or French colonialism - pushed their work toward an exploration of empire as a global phenomenon. Others considered the roots and meanings

\footnotetext{
${ }^{1}$ See for example Jeremy Adelman, 'What is global history now?', Aeon, 2 March 2017; Richard Drayton and David Motadel, 'Discussion: the futures of global history', Journal of Global History, 13:1 (2018), 1-21; Global History, Globally: Research and Practice Around the World, ed. Sven Beckert and Dominic Sachsenmaier (2018).

${ }^{2}$ Stuart Hall, 'The Local and the Global: globalization and ethnicity', in, Dangerous Liaisons: gender, nation and postcolonial perspectives, ed. Anne McClintock, Aamir Mufti and Ella Shohat (Minneapolis, 1997); Global History: interactions between the universal and the local, ed. A. G. Hopkins (Basingstoke, 2006).

${ }^{3}$ Frederick Cooper, 'What is the concept of globalization good for? An African historian's perspective', African Affairs, 100 (2001), 189-213; John Lonsdale, 'Globalization, ethnicity and democracy: a view from "the hopeless continent", in Globalization in World History, ed. A. G. Hopkins (2002).

${ }^{4}$ Jane Burbank and Frederick Cooper, Empires in World History: power and the politics of difference (Princeton, 2010); Globalization in World History, ed. Hopkins; P. Manning, 'African and World Historiography', Journal of African History, 54:3 (2013), 319-330; Crawford Young, The African Colonial State in Comparative Perspective (Yale, 1994).
} 
of creole identity, transnationalism, or cosmopolitanism, or the multiple, reciprocal dynamics underpinning oceanic communities. ${ }^{5}$ More generally, however, it is true that Africanist scholars occupy a peculiar place in the discipline. While Richard Evans could point toward the outwardlooking community of British Europeanists compared to the relative insularity of their continental colleagues, ${ }^{6}$ Africanists in the UK constitute a very small share of the 'market': we do (or at least represent) the 'wider world' in our academic departments, but our relevance to the field of global history is debatable given that we only represent a very small proportion of all historians in Britain part of the 13 per cent of historians who work on Africa, Asia, the Middle East, and Latin America. ${ }^{7}$

Still, it remains the case that increasing numbers of us think about the framing of African history in a global context. In so doing, however, we are confronted with the problem of how to relate the global to the lived experience of local actors, and the ways they think about the past. Central to that struggle is the need to get to grips with the contested nature of historical memory itself, as well as with dehistoricizing trends in certain quarters, not least in political circles. As foreign historians doing 'fieldwork' in our chosen areas, we are the agents of an intellectual globalism whether we like it or not, and perhaps unconsciously our frame is unavoidably global. The position of the historian is not, therefore, unproblematic, especially when conducting oral interviews, as in my own case. At the local level, there is an overwhelming concern for local history in a particular form, and historians from the West find that their own postmodernist parameters - whether these are subliminal or more overtly embraced - are alien to the concerns of local interlocutors: in Uganda, the desire to forge an explicitly national history, for example, and to carefully demarcate a Ugandan identity, in both spatial and temporal terms; and in Eritrea, the emphasis on the identity and ethos arising from lonely, violent struggle against a backdrop of perceived global neglect, giving rise to a solipsistic, militant territorialism. Even so, those concerns are linked to exogenous dynamics and, whether consciously or otherwise, local actors do indeed reflect on the global past, and articulate ideas about how the local context intersects with the larger flow of history beyond it.

My two case studies have deep global historical heritage - Eritrea, or at least its highland plateau and adjacent coast, as part of Axum and the Red Sea world, with direct links to the Eurasian core of antiquity; Uganda as the fulcrum of slow but seismic and globally significant population movements, that of the Bantu speakers in the course of the first millennium CE, which were among the most dramatic in human history. ${ }^{8}$ And yet both cases highlight local struggles with the global

\footnotetext{
${ }^{5}$ John Thornton, Africa and Africans in the Making of the Atlantic World, 1400-1800 (Cambridge, 1992, 1998); Pier Larson, Ocean of Letters: language and creolization in an Indian Ocean diaspora (Cambridge, 2009); 'Special feature: Africa and the Indian Ocean', Journal of African History, 55:2 (2014). See also the pathbreaking work by Paul Gilroy, The Black Atlantic: modernity and double consciousness (1993).

${ }^{6}$ Richard J. Evans, Cosmopolitan Islanders: British historians and the European continent (Cambridge, 2009).

7 'The long view: scholars assess the state of history', Times Higher Education, February 2018.

${ }^{8}$ David W. Phillipson, Ancient Ethiopia. Aksum: its antecedents and successors (1998); David Schoenbrun, A Green Place, A Good Place: agrarian change, gender, and social identity in the Great Lakes region to the $15^{\text {th }}$ century (Portsmouth NH, 1998); Christopher Ehret, 'Bantu Expansions: re-envisioning a central problem of early African history', International Journal of African Historical Studies, 34:1 (2001) 5-41.
} 
modernity of which they are a product. In both cases, there is an at least tacit - and, sometimes, explicit - focus on the profound rupture imagined in the moment of imperial contact, and on the violence of globalising colonial rule which is subsequently imposed upon them. Existential and epistemological challenges abound in an era of increased globalism, and of heightened identity politics which are frequently resistant to that globalism - although identity politics forged around the clash between local and global, while they have mutated over time, are not in themselves novel.

\section{HISTORY WARS:}

\section{UGANDA}

When he was at school in the early 1960s, in the final days of British rule, Yoweri Museveni - now President of Uganda - had a deep interest in history as an A-level subject. But it was not Africa's past that interested him. Rather, he was enthused by the study of European history: specifically, the French Revolution and the fundamental political and social change thus effected; and the unification of Germany and Italy, and the creation of conditions conducive to rapid economic, particularly industrial, growth. ${ }^{9}$ These were lessons that stayed with him. In the meantime, however, he developed a clear sense of Africa's place in global history - and his was not a positivist vision. While Europe was achieving remarkable economic development, underpinned by robust markets and political unity, Africa was in the grip of mindless tribalism; this, according to Museveni, was the continent's enduring "problem", a theme to which he has returned repeatedly over the last thirty years. ${ }^{10}$

It might reasonably be assumed that the time has long since passed that African historians had to bitterly but unavoidably set up that mustiest of straw men, Lord Dacre, Professor Hugh TrevorRoper, who had famously dismissed the study of the African past as a complete waste of time in his capacity as Regius Professor of Modern History at Oxford. ${ }^{11}$ There was a time when it was de rigueur to do so. ${ }^{12}$ Dacre himself was drawing on a well-established trope, first articulated by Georg Wilhelm Friedrich Hegel in 1822, when he described the continent, in essence, as lying outside of global history - a curiously ahistorical place, mired in its own terrible solipsism. It was "the land of childhood ... enveloped in the dark mantle of Night", as he famously put it. "It is no historical part of the World ... it has no movement or development to exhibit." ${ }^{, 13}$ But the ghosts of Hegel and Dacre pop up in unexpected places. Museveni appeared to be broadly in agreement with the basic idea, as he

\footnotetext{
${ }^{9}$ Yoweri Kaguta Museveni, Sowing the Mustard Seed: the struggle for freedom and democracy in Uganda (Oxford, 1997), 14.

${ }^{10}$ For example, see Yoweri K. Museveni, What is Africa's Problem? (Minneapolis, 2000), 163-4.

${ }^{11}$ Hugh Trevor-Roper, The Rise of Christian Europe (1965), 9-11.

12 A. G. Hopkins, An Economic History of West Africa (1973), 32; see also Finn Fuglestad, 'The Trevor-Roper Trap or the Imperialism of History: an essay', History in Africa, 19 (1992), 309-326.

${ }^{13}$ G.W.F. Hegel, quoted in Archives of Empire: Vol II: The Scramble for Africa, ed. Barbara Harlow and Mia Carter (Durham NC, 2003), 21, 28.
} 
sought to rebuild a nation ravaged by political catastrophe and economic collapse. He reflected a conviction widely held within the National Resistance Movement (NRM), Uganda's governing party since 1986, that the supposed accomplishments of the precolonial past, highlighted by Africanist scholars, had been greatly exaggerated. How could this not be the case, said Museveni, when all the evidence pointed to the inescapable fact that Africa was backward? To some extent Africa was undone by colonial rule, true; but even when one cast one's eye further back, all that could be beheld was perhaps the occasional noteworthy material achievement (an impressive earthwork here, a stylish vase there) but otherwise what looked very much like the unrewarding gyrations of barbaric tribes which had haunted Trevor-Roper's vivid imagination. This view constituted a distinctive strand of the new developmentalism which underpinned the political and economic projects of the late twentieth and early twenty-first centuries, eschewing the study of the past in favour of building the future, as though the two could and should be uncoupled.

Museveni's thinking represented just the latest stage in successive generations of Ugandans' imaginings about their role in the flow of global history. In the late nineteenth and early twentieth centuries, at the outset of British colonial rule, the people of Buganda - the kingdom at the core of the British colonial order and after which the Protectorate was named - were regarded as bright, outwardlooking, and worthy of British benevolence; they were receptive to change, and embraced the British imperial project with its distinctive historical trajectory. ${ }^{14}$ The Ganda certainly saw themselves in those terms: this was a melding of histories, encapsulated to some extent in the writings of Apolo Kagwa and Hamu Mukasa, and represented by their large-scale conversion to Christianity and their willingness to grow cotton, Britain's cash crop of choice in the area. ${ }^{15}$ Buganda, in other words, had entered the world, and become a part of global history.

A generation later, in the 1920s and 1930s, Ganda royalists worried about the loss of "traditional culture" as younger Ugandans clamoured to look and sound like foreigners. Kabaka (King) Daudi Chwa's short treatise on the subject, produced in 1935, extolled the virtues of precolonial tradition and the importance of understanding local history. ${ }^{16}$ (With hindsight, the sentiment was ironic, given that his own son, Edward Mutesa - kabaka from 1939 to 1966 - was privately educated, commissioned as an officer in the British Army, and spoke with the same received pronunciation as his English peers.) On this reading, foreign influence and the excessive zeal for buying into an exogenous vision of the global past was something to be feared, and resented. Indeed,

\footnotetext{
${ }^{14}$ Michael Twaddle, 'The Ganda receptivity to change', Journal of African History, 15:2 (1974), 303-315; for a contemporary assessment of Buganda's supposed capacity for progress, given the correct tutelage, see A.M. Mackay (ed. by his sister), A.M. Mackay, Pioneer Missionary of the Church Missionary Society to Uganda (1890).

${ }^{15}$ Apolo Kagwa (ed. \& tr. M.S.M. Kiwanuka), The Kings of Buganda (Nairobi, 1971; $1^{\text {st }}$ ed., 1902); Hamu Mukasa (ed. Simon Gikandi), Uganda's Katikiro in England (Manchester, 1998; $1^{\text {st }}$ ed., 1904); Cyril Ehrlich, 'The Uganda Economy, 1903-1945', in History of East Africa, Vol II ed. V. Harlow \& E.M. Chilver (Oxford, 1965).

16 'Education, civilisation, and "foreignization". The Kabaka's Pamphlet, 1935', in The Mind of Buganda: documents of the modern history of an African kingdom ed. D. A. Low (London, 1971).
} 
it was a struggle which intensified at the very heart of the Buganda kingdom over the ensuing decades, and especially as independence approached in the course of the 1950s. While many Ugandan nationalists embraced a unitary, modernist vision of the independent nation - one freed from the cloying anachronism of monarchy and 'tribe', and drawing on more global histories of socialism or Pan-Africanism for succour and inspiration - others, notably in Buganda, were anxious at the prospect of their own history becoming subsumed within a larger entity. Ganda neo-traditionalists responded by forming the Kabaka Yekka (KY) movement - the Luganda term means 'the King alone' - which argued for autonomy, even outright secession, from a future independent Uganda, and which eschewed the globalism implied by the ostensibly more progressive politics of the Uganda People's Congress (UPC), or the Democratic Party. ${ }^{17}$ Importantly, these were not simply, or not only, presentist debates about future status, reflecting a divided nationalist politics. They were also arguments over the nature of history itself, and reflected a growing chasm between those who embraced a global historical order (manifest in the British imperial project) in their pursuit of political legitimacy, and those who expounded the virtues of 'tradition' and ethnicity as the defining principles of sociopolitical organisation, and who feared the disappearance of those principles in a unitary future. ${ }^{18}$ Ironically, there were many in Buganda - the bedrock of the colonial order, and the supposed agent of global modernity half a century earlier - who now felt that the kingdom had most to lose from the latter.

They were right to be afraid, as it turned out; by the late 1960s, after a brief strategic alliance between KY and Milton Obote's UPC government, Buganda and the other kingdoms had been abolished as Obote embarked on a programme of socialist modernization. ${ }^{19}$ But the struggle, the central dichotomy - between a local and a global past - was perennial, and in evidence elsewhere. It was captured in the work of Acholi poet and playwright Okot p'Bitek: the epic poem Song of Lawino, first published in 1966, is performed in the first person by Lawino, who laments - in alternately trenchant, sorrowful, comical and bitter terms - the fact that her husband (Ocol) has abandoned African culture and tradition, dresses and behaves like a European and seemingly aspires to be white, and has taken up with Clementine, an African woman who has likewise adopted European ways. p'Bitek gave Ocol a scathing reply, in Song of Ocol ${ }^{20}$ Taken together, the poems - in which the lead characters pile insults on one another - encapsulate the global/local conundrum, with implicitly or explicitly historical strains. In the political realm, as Obote's authoritarianism hardened, the opposition Democratic Party under the leadership of Benedicto Kiwanuka sought self-consciously to

\footnotetext{
${ }^{17}$ I.R. Hancock, 'Patriotism and neo-traditionalism in Buganda: the Kabaka Yekka ("the King Alone") movement, 1961-62', Journal of African History, 11:3 (1970), 419-434.

18 'Annexure to the Appeal by Kabaka Mutesa II to the Secretary-General of the United Nations, 11 March 1966', in Mind of Buganda, ed. Low, 222.

${ }^{19}$ D. A. Low, Buganda in Modern History (1971), 245-6.

${ }^{20}$ Both poems are in Okot p'Bitek, Song of Lawino \& Song of Ocol (Johannesburg, 1984). They were first published in 1966 and 1967 respectively.
} 
evoke the language of global human rights and democracy, and joined their vision of the nation to a whiggish interpretation of global history. They drew parallels, for example, with the American revolution and the liberal ideals which thereafter seemed to undergird a global political narrative. ${ }^{21}$ It was no coincidence that Kiwanuka himself was a Roman Catholic Muganda - Catholics had long felt marginalized by the royalist establishment in Buganda - and belonged to a group of Ganda who eschewed the narrow, traditionalist monarchism of Kabaka Yekka and embraced a much more global vision of nationalist politics and political freedoms. This central cleavage in Ganda politics - whether to be open to the world, or culturally protectionist - could be traced to the turbulent nineteenth century, when the world itself first intruded on Ugandan societies. ${ }^{22}$

Since the catastrophes of Idi Amin in the 1970s and the violence of the early 1980s, these history wars have persisted and, if anything, have intensified. But this is not simply the preserve of political elites, concerned with various versions of national history. Ordinary citizens have likewise developed locally-rooted historical narratives which are used to critique both global history and historic globalization - again, frequently interchangeable concepts. It is important to stress that these 'external forces' are conceptualised on multiple levels. Firstly, and most obviously, they are explicitly historical - most dramatically manifest in the arrival of long-distance commerce and, ultimately, British imperialism and colonial rule in the late nineteenth and early twentieth centuries. Secondly, however, they are evident in foreign cultural influences which are often framed in negative terms bad music, sexually promiscuous women, or depraved homosexual men are frequently understood as the products of 'foreign influence'. And thirdly, the government itself is seen as the agent, and is emblematic of, a brutal political and economic globalism - manifest in authoritarian developmentalism and neoliberal economics which produces a political elite linked to overseas investors from China, India, or the Gulf States; an elite which extols the virtues of an ahistorical patriotism in ordinary Ugandans but which in reality acts with criminal neglect toward its own citizens. Visions of the local versus ideas about the global past need to be understood in this context. Extensive interviewing of a range of Ugandan informants in recent years reveals something of an entrenchment of the view that the forces of global modernity have disrupted Uganda in unpleasant ways. This no doubt reflects disillusion with both the perceived predations of globalization and with the agent of those predations, a stubborn and increasingly authoritarian regime which has sought to 'modernize' Uganda and which projects negative visions of local history. Localized histories have come to the fore, and the deeper, precolonial past - histories of neatly quarantined, pristine tradition before the irruption of external forces - is romanticized as a means of critiquing the perceived tyranny of global historical forces which have pushed people to the economic and political margins. ${ }^{23}$

\footnotetext{
${ }^{21}$ Ben Kiwanuka's preface in Forward to Freedom, being the manifesto of the Democratic Party (Kampala, 1960).

${ }^{22}$ See for example H. M. Stanley, Through the Dark Continent (1899; $1^{\text {st }}$ ed., 1878), Vol I.

${ }^{23}$ This formed part of a Leverhulme Trust-funded project between 2012 and 2015 concerned with historical culture and consciousness in Uganda since the mid-nineteenth century. In their interviews, conducted in selected
} 
Notably, informants frequently emphasized the pristine nature of local history at some point in the past being 'passed down' in moral and instructive terms - a strikingly orientalist trope familiar to anyone with a passing acquaintance with ideas about supposed 'primitive wisdom', and perhaps self-consciously reclaimed by modern informants. In this scenario, we have the imparting of knowledge, the confirmation of origins, the exhortation to cultural purity and convention - often expressed through riddles, proverbs, and stories; the lessons of time presented in the abstract. ${ }^{24}$ Informants stressed how the deeper past - what might once have been called 'traditional history', or more recently, perhaps, 'ethno-history ${ }^{, 25}$ - occupied a central place in the temporal imaginary of a bygone age. Elders sat around the flickering flames and imparted cultural wisdoms, offering a vision of both serenity and stability. It was a simpler time. This romantic, emotional process of reconstruction served many purposes, no doubt, but it certainly spoke to the rupture and violence and discontent of the modern age. "In the evenings", said one informant, "older relatives would gather around fire places and educate their children and grandchildren about...past experiences i.e. how man came into existence, where they came from..." Acquaintance with the past instilled ideas about proper, decorous behaviour, notably in terms of sexual chastity and propriety. (This particular informant referenced the anti-homosexuality bill then advancing through the Ugandan parliament as the product of those enduring conservative values. $)^{26}$ Homosexuality, the subject of angry debate in contemporary Uganda, is for some the product of a creeping, nefarious, global culture which first intrudes upon Ugandan communities in the late nineteenth century. ${ }^{27}$ The 'precolonial past' represented political charters of local origin and settlement. Narratives demonstrated provenance and the rightful occupation of land, for example. ${ }^{28}$ History was about space protected from outsiders whether aggressive immigrants, greedy governments, or, more recently, Chinese or Indian investors but it was also consistently linked with morality and "values". The past was thus a cultural and psychological realm as well as a physical arena. ${ }^{29}$ For others, against a backdrop of spiralling living costs and the ravages of neoliberalism, the precolonial past offered ample evidence of economic coping mechanisms - the gathering of food during famine, for example - and was salutary in terms of what it revealed about "the high level discipline in society", and the positive outcomes of communal

communities across the country in the attempt to achieve geographical spread, the research team aimed for a cross-section in terms of age, gender, and occupation. Informants included teachers, priests, farmers, shopkeepers and traders. They were asked - in a mixture of English and vernacular languages - about the importance of 'national history', and of history as a subject more broadly, including as taught at school. What follows is a modest sample of those interviews, which are anonymized to protect informants.

${ }^{24}$ Interview, Bugobero, farmer, c.43 years old, 25 January 2014.

${ }^{25}$ There is a wider literature exploring these issues: see for example History and Ethnicity, ed. Elizabeth Tonkin, Maryon McDonald \& Malcolm Chapman (London and New York, 1989); Recasting the Past: history writing and political work in modern Africa, ed. Derek R. Peterson and Giacomo Macola (Athens OH, 2009).

${ }^{26}$ Interview, Bugobero, teacher, c.35 years old, 26 September 2013.

${ }^{27}$ See for example Apolo Kagwa, cited in Sylvia Antonia Nannyonga-Tamusuza, Baakisimba: Gender in the Music and Dance of the Baganda People of Uganda (New York, 2005), 212.

${ }^{28}$ Interviews in Bubutu, unemployed, c. 40 years old, 15 January 2014; Bugobero, teacher, c. 35 years old, 26 September 2013; Mbale, teacher, c. 28 years old, 26 January 2014.

${ }^{29}$ Interview, Mbale, teacher, c.28 years old, 26 January 2014. 
living. ${ }^{30}$ For some, knowledge of 'history' - by which was frequently meant 'traditional custom' enabled one to avoid "bad behaviour", thanks to the taboos laid down by ancestors. ${ }^{31}$ Yet of course there was a degree of careful selection among informants and interviewees - and this could come out in interesting, sometimes paradoxical, ways. So, while one informant, for example, recalled as a boy listening to elders talk about "tribal wars" - an early memory of how history "mattered' in his community - he was clear that the precolonial past provided lessons in "love" and "unity". ${ }^{2}$ For one farmer from the Mbale area, history inculcated a sense of "good values", respect for customs, upright behaviour, and respect between people - despite the fact that much of the history he remembered at school involved migrations and, again, "tribal wars". ${ }^{33}$

For some, the precolonial past had been the time of true democracy, and the lessons were there for the learning; but this "has been eroded by selfish politicians who have not picked a leaf from history," asserted one informant. The incumbent NRM regime had learnt nothing from this deeper well of experience and wisdom: "The current government's attitudes [toward] history [are] oblique, being overshadowed by generations of modernity and Western influence." 34 The implication is clear enough - that the intrusion of Western history and political culture into Uganda had produced grasping, authoritarian regimes whose behaviours were contrary to ancient indigenous practice. "Modern civilisation", indeed, in a wonderfully simple summation of much of the argument underpinning this paper, "tends to outdate our historical past." ${ }^{.35}$ Moreover the absorption of Ugandan communities into a unitary nation, the most dramatic legacy bequeathed by global imperialism, was scarcely a matter for celebration. "Uganda has [a] distorted history of the various ethnic groups that populate it", suggested one Gisu informant. "Uganda's national history is that of political crooks who mainly misinform the public instead of genuinely mobilising them for development. Uganda has no national history or culture to talk about. It is a dysfunctional society that is only getting worse." ${ }^{" 36}$ For others, national history might be traced to the "coming of colonialists", but even then it was mostly "tribal history", rather than a discernible national past. ${ }^{37}$ Informants were keen to point to the fact that the current regime, like those before it, was essentially disinterested in history because it supposedly undermined its modernist credentials and compromised its globalizing outlook: "Governments tend not care so much about history. They tend to adopt Western ways of life management... [and] pay more attention to science from western cultures." 38 The government evidently believed that "the

\footnotetext{
${ }^{30}$ Interview, Bugobero, teacher, c.35 years old, 26 September 2013.

${ }^{31}$ Interview, Mbale, teacher, c.28 years old, 26 January 2014.

32 Interview, Mbale, teacher, c.50 years old, 1 February 2014.

${ }^{33}$ Interview, Mbale, farmer, c.60 years old, 24 January 2014.

${ }^{34}$ Interview, Bugobero, teacher, c.35 years old, 26 September 2013.

${ }^{35}$ Interviews in Bugobero, farmer, c.43 years old, 25 January 2014; Mbale, teacher, c. 28 years old, 26 January 2014.

${ }^{36}$ Interview, Mukono, agricultural consultant, c.40 years old, 22 January 2014.

${ }^{37}$ Interviews in Mbale, teacher, c. 28 years old, 26 January 2014; Kitindya, priest, c.50 years old, 6 February 2014.

${ }^{38}$ Interview, Mbale, teacher, c.28 years old, 26 January 2014.
} 
values of long ago are outdated", and as a result, despite the current government's own putative agenda to eradicate division, this had bred disunity and sectarianism. ${ }^{39}$

On the other hand, belief in a rather more depressing continuity emerged when informants were asked to survey the behaviour of 'government' over la longue durée - a continuity which also highlighted a certain paradox in this affective, idealised vision of the deeper past. "Politics to-day favours only the rich", intoned one informant. "Even in pre-colonial days, leadership was for the wealthy families and even hereditary. It has changed only with the introduction of democracy ..." There was no substantive difference between past and present: "The recent Ugandan governments were dictators and murderers, they used their powers and authority to oppress and exploit their subjects as it was the case in the precolonial times as leaders made decisions without considering the fate of their subjects." ${ }^{40}$ But here again, the political past is mobilised to condemn the modern state: they are all the same, political leaders, and they always have been. ${ }^{41}$ And history, at least, equipped those willing to accept its lessons to gather such insights, for it instilled "the power of reasoning", according to one informant. ${ }^{42}$

More broadly, a fixation with 'the modern' had blinded Ugandans to the lessons of the past. In particular, a supposedly universalist, modernising education system had depleted the values of the precolonial, and as a result young people had no regard for this kind of history and thought only of their career prospects. They only studied, and valued, the kinds of things that would facilitate this naturally enough. ${ }^{43}$ Others went further. When asked whether young Ugandans prized the study of history, one informant asserted baldly: "Largely, they do not. They would rather act ... more European than the Europeans themselves. They hate their own identity because throughout history we seem as a people to have failed to make significant progress ... In time they will implode and then find themselves without reference [points] $" .{ }^{44}$ It was a common perception. ${ }^{45}$ Children needed to learn history as a foundation for their becoming "good citizens". ${ }^{46}$

But the young were ever the source of anxiety. "Today our youth have a different lifestyle their needs are pinned to the Western world ... They think the past belongs to the older generation." ${ }^{\text {47 }}$ For another informant, "broader society considers the precolonial past irrelevant. Most of them, especially the youth, are concentrating on copying foreign culture ... Young people don't think much about history because they are taken up with foreign culture ... [T] he problem is they no longer stay

\footnotetext{
${ }^{39}$ Interview, Mbale, teacher, c.50 years old, 1 February 2014.

${ }^{40}$ Interview, Bubutu, unemployed, c.40 years old, 15 January 2014.

${ }^{41}$ Interviews in Mukono, agricultural consultant, c.40 years old, 22 January 2014; Mbale, teacher, c.28 years old, 26 January 2014.

42 Interview, Bubutu, unemployed, c.40 years old, 15 January 2014.

${ }^{43}$ Interview, Bugobero, teacher, c.35 years old, 26 September 2013.

${ }^{44}$ Interview, Mukono, agricultural consultant, c.40 years old, 22 January 2014.

${ }^{45}$ Interview, Kitindya, priest, c.50 years old, 6 February 2014.

${ }^{46}$ Interview, Mbale, farmer, c.60 years old, 24 January 2014.

${ }^{47}$ Interview, Hoima, priest, c.60 years old, 17 January 2013.
} 
in our traditional setting." ${ }^{48}$ Damned modernity, for tradition is set to flight: "The problem", asserted one informant with evident distaste, "is that most of our children don't read serious things and their role models are Chameleon, ${ }^{49}$ Bobi Wine,${ }^{50}$ Beyonce, etc.” Here, interestingly, our informant emphasized that for his generation, global history offered important reference points and inspirational icons: "For us who were born earlier our role models were Socrates, Gamal Nasser, Kwame Nkrumah, Napoleon, Machiavelli, Sadat, Senghor and their likes. We like to learn more. Youth now only want money not knowledge and worse still historical knowledge which they find so distant and seemingly irrelevant because of their shallowness. ${ }^{, 51}$ Harsh, but hardly novel, with echoes of the anxieties expressed by Daudi Chwa in the 1930s. It is, unquestionably, a perennial gripe: the inevitable complaints on the part of the old about feckless, callow youth.

The cost of not knowing history was high: it left people feeling "confused and empty", according to one informant. ${ }^{52}$ "You may avoid being eaten by a lion if you listen to elders who know where it hides", as one interviewee expressed it. ${ }^{53}$ History was a living, curative entity; a pool of sagacity; oracular and didactic. History was a guide to the future, full of lessons for those willing to learn them, and even more specifically, as a means to unity, for all Ugandans can learn about one another and join forces, asserted another informant. ${ }^{54}$ It is a significance attached to the past often heard, in a manner a world away from the contested, revisionist, postmodernist debates of the professional academy of the Global North. Ultimately, precolonial history, claimed one informant, "is the true history of our people before it was adulterated by the colonial powers through their forms of education and religion. It is therefore important if we want to understand our real selves and what shaped/influenced attitudes/perceptions/culture and other aspects of our society." 55 The notion of "the true history of our people" is revealing, and hugely significant: it encapsulates the idea that there is a temporal cut-off point - the moment of imperial contact, colonial rule, globalization - at which history becomes less 'real', less authentic, certainly less believable. History is a journey; it is a form of therapy, and a source of knowledge and wisdom. It is "empowering", said one informant. "Precolonial history is particularly important because today when we lose our way, we try to look back and try to see where we came from and discover where we have gone wrong."

Yoweri Museveni's evident despair over the history of the nation, then, is shared by many Ugandans, but for very different reasons. For Museveni, the nation had failed - or come mightily

\footnotetext{
${ }^{48}$ Interview, Hoima, priest, c.60 years old, 17 January 2013.

${ }^{49}$ Chameleone is a Ugandan Afrobeat singer, born Joseph Mayanja.

${ }^{50}$ Born Robert Kyagulanyi, Bobi Wine is a popular musician who made international headlines briefly in 2014 when he was denied a UK visa on account of his virulently homophobic lyrics. He is now a political activist and an increasingly vocal and influential critic of Museveni.

${ }^{51}$ Interview, Bulucheke, trader, c.45 years old, 20 February 2014.

52 Interview, Mukono, agricultural consultant, c.40 years old, 22 January 2014.

${ }^{53}$ Interview, Bulucheke, trader, c.45 years old, 20 February 2014.

${ }^{54}$ Interview, Manafwa, local councillor, c. 67 years old, 20 October 2013.

${ }^{55}$ Interview, Bulucheke, trader, c.45 years old, 20 February 2014.

${ }^{56}$ Interview, Hoima, priest, c.60 years old, 17 January 2013.
} 
close to it - because of the local, 'sectarian' interests which characterize Uganda's precolonial past; but for many Ugandans, those interests are all that matter in the face of a brutal, detached state which is the product of global historical forces over which they have little control.

\section{LONELY Planet:}

\section{ERITREA}

Although the two have much in common in many ways, Eritrea offers a somewhat different case study from Uganda. There is comparatively little of the kind of source material from the earlier twentieth century which we have in abundance for Uganda, and so our analysis is inevitably centred in the more recent past - or more specifically, the popular consensus around that recent past, which is presented below. ${ }^{57}$ Further, as in Uganda, local interlocutors often conflate globalization and global history; but in Eritrea, the sense of explicitly historical trajectory is much more prominent in national psychology and self-image, and is readily articulated by both the leadership and ordinary citizens. Moreover, while Uganda is an increasingly authoritarian state, Eritrea is in a league of its own in this respect: its political space is much more tightly controlled, and therefore formal interviewing is difficult. Much of the following is based on more or less informal 'interviews' and conversations around historical memory and lived narrative, mostly gathered at a particularly traumatic moment in Eritrea's modern history - namely the years immediately before, during, and after the recent war with Ethiopia. ${ }^{58}$ Nonetheless, the central theme emerging from these is that Eritrea has long been excluded from the mainstream of global history, and that cycles of violence are at least partly the outcome of such marginalisation.

At Eritrea's annual independence celebrations, President Isaias Afeworki is wont to offer comments on the country's troubled past. It has become a ritual in the national calendar, and a desperately monotonous one for many citizens, but one which is dutifully broadcast on state television. ${ }^{59}$ The underlying message is supposed to be uplifting - how the young nation has made progress, how it remains resilient in the face of various challenges, and so on - but it is in fact a grim trawl through the trials and tribulations of Eritrean history: its subjugation as a colonial possession, its

\footnotetext{
${ }^{57}$ For an exception, and one which hopefully marks the beginning of a new field of research, see James de Lorenzi, Guardians of the Tradition: historians and historical writing in Ethiopia and Eritrea (Rochester NY, 2015).

${ }^{58}$ Formal citations are therefore unavoidably truncated. The vast majority of informants were either former guerrilla fighters from the liberation war of the 1970s and 1980s, many of whom were now government officials; or current national service recruits, who made up a substantial proportion of Eritrea's youth. Some of this material has been written up in Richard Reid, Shallow Graves: a memoir of the Eritrean-Ethiopian war (London, forthcoming).

${ }^{59}$ See for example https://www.youtube.com/watch?v=NmqFD0- oN8\&t=1150s; and http://www.eriswiss.com/president-isaias-afewerkis-speech-on-the-occasion-of-the-26th-independence-daycelebrations/
} 
betrayal at the hands of a brutal international order, its ongoing abuse and/or neglect by the international community. It is an exercise in the reification of Eritrea's national history in the context of a malign global past: Eritrea's place in that past is that of ill-treated corner of the world, compelling its people, through seemingly endless struggle and sacrifice, to transform itself into an independent state. But this is not just the idiosyncratic view of a seemingly immovable President. The core idea - a history of isolation and neglect - resonates with Eritreans, even if many of them blame him and his movement, the Eritrean People's Liberation Front (EPLF), for bringing this situation about, or at least exacerbating it.

It is a narrative which in some ways has its roots in 1962, when Ethiopia annexed Eritrea in violation of a federal arrangement put in place a decade earlier and supposedly guaranteed by the UN Security Council. ${ }^{60}$ The UN did nothing at that moment, and the armed struggle which had begun the year before in the country's western lowlands escalated dramatically in the course of the 1960s. But nationalist guerrillas would also point to the events preceding the annexation as evidence of the country's neglected status, and as reinforcing the idea of lonely, violent liberation as the nation's destiny. In the late 1940s, the future of Eritrea - a former Italian colony and now under temporary British administration - was discussed first by a commission of the main wartime allies, and then by the UN itself in one of the first such cases for the newly formed organisation. There were local consultations, with a select group of Eritreans who were asked whether they preferred full independence, or union with Ethiopia, which laid claim to the territory on cultural and historical grounds. The outcome of those consultations was inconclusive - there was vocal support for both options - but in the meantime the US had quietly decided that an independent Eritrea was emphatically not in American interests. An agreement was reached between the Truman administration and Haile Selassie's government involving US support for Eritrea being 'federated' with Ethiopia - though it was to have its own assembly, and considerable autonomy - in exchange for a major US military base on the outskirts of the capital, Asmara. (For a number of years Kagnew station in Asmara was the largest such US base in the world.) The British pulled out in 1952 - not before dismantling and selling off much of the territory's infrastructure, another key grievance in the nationalist memory - and the federation came into being. But for much of the next decade, Ethiopia systematically undermined Eritrean autonomy - removing the flag, banning the languages of government (Tigrinya and Arabic), and steadily closing down the political space - until finally abolishing the Eritrean assembly in $1962 .{ }^{61}$

The period between the late 1940s and the early 1960s was thus a seminal moment, in the view of later nationalists. This was the moment in which it was made clear that Eritreans were

\footnotetext{
${ }^{60}$ Ruth Iyob, The Eritrean Struggle for Independence: domination, resistance, nationalism 1941-1993 (Cambridge, 1995), chap. 5.

${ }^{61}$ See for example G.K.N. Trevaskis, Eritrea, a Colony in Transition (1960); Roy Pateman, Eritrea: Even the Stones Are Burning (Lawrenceville NJ, 1998).
} 
irrelevant in the Cold War global order: the cash-strapped British had barely managed the territory, and then asset-stripped it before scurrying off; the Americans had betrayed the country with shocking disregard for local concerns (John Foster Dulles had famously declared that while he had some sympathy with their desire for independence, there were greater issues at stake in a volatile region ${ }^{62}$ ); and the grasping and backward Ethiopians had proceeded to brutalize and oppress Eritreans with impunity. All of this was framed in historical terms, and convinced a cohort of nationalists schoolchildren in the 1950s, guerrillas in the 1960s - that the history of British imperialism was that of larceny and perfidy; that the supposed history of American liberalism was an artifice which disguised an imperialism no less avaricious or mendacious than of Britain; that a global order centred on the UN had evolved which took no account of the oppressed peoples of the world and which was in any case was controlled by an oligopoly of major powers. The forces of global history, in other words, were fundamentally hostile to Eritrea, which was thus going to have to find its own way in the world - to carve its own path, and Frantz Fanon, whose exhortation to anticolonial struggle in the Algerian context served as a global rallying call, offered inspiration. ${ }^{63}$

Ironically enough, it was Eritrea's earlier incarnation as an Italian colony - between the 1890s and 1941 - which reinforced the nationalist notion of essential difference from Ethiopia. Indeed, for at least some Eritreans in the 1940s and 1950s, the fact that they had been governed by a putatively 'advanced' foreign power justified their demands for independence from Ethiopia, which was feudal, regressive, undeveloped; Eritrea, by contrast, had experienced 'development', of a kind, and had experienced at least some of the accoutrements of supposed modernity. Even Eritrean unionists those who feared a return of European imperialism, and who believed that union with Ethiopia would best serve Eritrean interests and was in effect an exercise in African nationalism - privately or otherwise believed Ethiopia to be a somewhat backward country, and Eritreans (or at least Eritrean Tigrinya) to be really rather superior. ${ }^{64}$ It was a curious reworking of Italian colonialism, with its record of under-educating Eritreans, of racial segregation, and of frequently ill-conceived development projects. But the overriding point was that, however harsh the experience, governance by a foreign power had raised Eritrea to a status from which incorporation into feudal Abyssinia had could have no legitimacy. In a strikingly teleological argument, imperialism was the sine qua non of the nationalist cause. ${ }^{65}$ There was an additional irony in that Eritrea was not actually supposed to exist, in this form anyway: Italy had originally occupied the plateau as a launching pad for its invasion and occupation of Ethiopia, a project which unravelled spectacularly with Italy's defeat by Emperor Menelik's army at the battle of Adwa in 1896. Eritrea was, then, the product of imperial failure.

\footnotetext{
${ }^{62}$ Okbazghi Yohannes, Eritrea: a pawn in world politics (Gainesville FL, 1991), 103.

${ }^{63}$ Frantz Fanon, The Wretched of the Earth (1967).

${ }^{64}$ Interview with former member of the Unionist Party, Asmara, 31 August 2006.

${ }^{65}$ For an overview of the Italian period, see Redie Bereketeab, Eritrea: the making of a nation, 1890-1991 (Trenton NJ, 2007), chap. 4.
} 
In the 1960s and 1970s, as the violence of the liberation struggle engulfed Eritrea, the wonderful examples of Art Deco architecture in Asmara - arguably Italy's most enduring legacy became curious anachronisms, reminders of a distant epoch. The EPLF, the dominant liberation front from the early 1970s, honed its political vision in the northern mountains, a political vision underscored by a distinctive conceptualization of the territory's global past. The isolation of the struggle, and the militant solipsism it engendered, compounded the vision. There was little external support - a key shibboleth of the EPLF's war - and as a result a culture of complete material and military self-reliance evolved, which was quickly extended into the realms of ontology, politics and history. The EPLF would operate according to its own temporality, its own sense of mission and special destiny: Western liberal time was rejected, just as Soviet-inspired Marxism was eschewed as simply another form of foreign hegemony. ${ }^{66}$

After independence in 1991, achieved through military victory and the collapse of the Ethiopian socialist regime, the Eritrean government under Isaias Afeworki and the leadership of the EPLF sought to recreate the visions of the armed struggle in wider society, with mixed results. But when war with Ethiopia re-erupted in 1998, it seemed that the isolation that had been framed as a virtue was now a dangerous burden. Compared to Ethiopia's long-standing place in the international order, which it occupied with ease, underpinned by a deep historical relationship with that order, Eritrea came across as angry, trenchant and laconic; ill-at-ease in diplomatic circles; convinced of the righteousness of its own position without necessarily having to justify itself to external powers undeserving of detailed explanations. This was not merely political inexperience, although for sure there was some of that. It was the outcome of an explicitly historical lens through which the nation and its place in the world was viewed. During the war itself, as yet another lonely, bitter cycle of violence ravaged yet another generation of young men and women, Eritreans bemoaned in private the dreadful trajectory which had led them to this position, and reflected on the nature of their history. They reflected, in particular, on the waves of imperialism and domination which seemed to characterise Eritrea's experience of the global past, and which had apparently necessitated the kinds of violence which had ultimately led to the young nation's partial quarantine from the world. There was increasing criticism - again, in private - of the EPLF and of Isaias, and despair at the direction the nation was taking; but when the President spoke of the gruesome past, and the seclusion which had characterised that past, people had no reason to doubt it. They were living it. ${ }^{67}$

In the years after the war, time itself weighed heavily on those millions of Eritreans trapped in a system of indefinite national service, but the government continued to exhort them to be vigilant, and to sacrifice themselves in defence of a nation beleaguered, and surrounded by enemies. The

\footnotetext{
${ }^{66}$ For EPLF visions, and supportive assessments of those visions, see: Behind the War in Eritrea, ed. Basil Davidson, Lionel Cliffe and Bereket Habte Selassie (Nottingham, 1980); James Firebrace, with Stuart Holland MP, Never Kneel Down: drought, development and liberation in Eritrea (Trenton NJ, 1985); The Long Struggle of Eritrea for Independence and Constructive Peace, ed. Lionel Cliffe and Basil Davidson (Trenton NJ, 1988).

${ }^{67}$ Author's field notes and informal interviews, Eritrea, between May 1998 and September 2002.
} 
national calendar was peppered with events - Independence Day, Martyrs' Day, 1 September (marking the start of the armed struggle in 1961), festivals celebrating Eritrean heroism and achievement at Sawa, the national military training centre - which were opportunities for the President to remind an increasingly exhausted population of the lessons of global history. And for good measure, there would be performances to act out that history - often involving rubber dragons (representing the forces of colonialism and imperialism) being slayed by heroic fighters. ${ }^{68}$

There was one last twist in the tale - to date. Eritrean identity had long been remarkably diasporic. Since the first activists went into exile in the 1950s, and the refugee community in Italy, Sweden, Germany, the US, Australia, and elsewhere, swelled in the 1970s and 1980s, Eritrean citizenship and nationality became entwined with new, more global identities, and Eritreans joined their own turbulent histories with those of their host nations. Now, from the early 2000s, they were complemented by a new cohort, as increasing numbers of Eritreans fled the country through Ethiopia or Sudan to escape interminable military service and economic hardship. The unfortunate ones died on the journey, or were trafficked across the Sahara, or were trapped in holding centres in third countries, or drowned in the Mediterranean. ${ }^{69}$ The 'lucky' ones reached Calais, desperate to enter the UK, long seen as a haven and a place where lives could be rebuilt, and where education and employment were possible. ${ }^{70}$ It represented a veritable movement of Time itself: the mass rejection of EPLF Time and the desire to rediscover a different, more global kind of Time, one which perhaps moved a little more briskly and in which there were rather greater opportunities for self-expression and self-realisation. The desperation to reach Britain was also a curious kind of global historical feedback: few Britons were probably even aware of Britain's role in Eritrea in the 1940s and 1950s, a seminal moment in the histories of both countries, but public discourse in the UK was increasingly dominated by the need to control immigration, the perils of admitting asylum-seekers, and - in the wake of the EU referendum - the amorphous visions of an imperial past in which Britain was great and globally dominant. ${ }^{71}$ A swathe of the British political class - and many British people themselves - seemed to hanker after a particular vision of the global past; many Eritreans, likewise, aspired to a version of global history which was not rooted in visions of cyclical violence, militarized isolation, and unending personal sacrifice. It was a curious intersection of historical aspirations.

\footnotetext{
${ }^{68}$ Author's field notes and informal interviews, Eritrea, between December 2002 and August 2008. See also Richard Reid, 'Mourning and Glory: toward affective histories of violence in Africa over la longue durée', Emotions: History, Culture, Society, 1:1 (2017), 113-136.

${ }^{69}$ Council on Foreign Relations, 'Authoritarianism in Eritrea and the Migrant Crisis', 16 September 2016 (https://www.cfr.org/backgrounder/authoritarianism-eritrea-and-migrant-crisis)

${ }^{70}$ Author's conversations with asylum seekers in London, since c.2002.

${ }^{71}$ Sally Tomlinson \& Danny Dorling, 'Brexit has its roots in the British Empire - so how do we explain it to the young?', New Statesman, 9 May 2016; Julianne Schulz, 'Why the dream of Empire 2.0 is still "cobblers", The Guardian, 11 February 2018.
} 


\section{CONCLUSIONS:}

\section{THE WORLD FROM BELOW}

How best do we go about conceptualizing 'global history' while doing justice to the views of the local? This is a challenge for all historians from the global north who are themselves agents of a scholarly globalism on which their local interlocutors often have, at the very least, a rather different perspective. In some respects, this is a gulf which has, if anything, widened in recent decades, and represents a methodological, epistemological, and pedagogical struggle between the global and the local with all historians of Africa must eventually engage. Ultimately, what does our area-specific history mean in a global world? How do we make our research relevant and legible? In an age of epistemological uncertainty, and indeed anxiety, an exploration of the connection between the local and the global seems critically important.

The issue is given further urgency by the fact that, increasingly, our students have roots in the very regions on which we do our research, with distinctive perspectives on the scholarship we bring before them. If we discover - as in Uganda and Eritrea - particular visions on 'the global' in the regions themselves, we also find a student body which demands much more in the way of global perspectives because of their own multiple and overlapping identities, and thus their own politics, than might once have been the case in the university. It is no coincidence that these young people are frequently in the vanguard of the 'decolonizing the curriculum' movement. ${ }^{72}$ In class, I have certainly found myself facilitating, or at least moderating, the expression of a particular form of global historical consciousness. To a considerable extent, decolonizing the curriculum therefore means globalizing it, while in the process de- (or re-) centring the world itself - including taking into account how diasporas think about the local to which they have familial and cultural links. But in other ways, it also means localizing it, and certainly getting to grips with how local actors perceive and interact with the global.

It is vital that the views of Ugandans and Eritreans as briefly surveyed here are brought into the larger debates referenced at the beginning of this paper. For sure, their distinctive visions of the global past are indicative of the desire - the need, even - for stable, usable, national and local histories; school and university curricula in turn are often conceived around a nationally- or locallybounded temporality, in ways that would seem 'outdated' to Western eyes. In many ways, global, or transnational, histories offer little in the way of succour to the local actors whose views underpin this paper. And yet, almost everyone - excepting, perhaps, jealously self-interested political elites, as in Eritrea - might find that locating their histories in a multi-sited global past offers rich and interesting rewards. That is a project for the future. Suffice to conclude with the observation that my own

\footnotetext{
${ }^{72}$ For example, Priyamvada Gopal, 'Yes, we must decolonize: our teaching has to go beyond elite white men', The Guardian, 27 October 2017.
} 
approach to global history as a field has been profoundly influenced by the voices I have encountered over a number of years in Uganda and Eritrea, and elsewhere in the region. It has never been more important to provide a more robust, supportive environment for the expression and exploration of the local - wherever that takes place - which is where the global begins, and, perhaps, where it ends, too. At least it seems so for millions of Ugandans and Eritreans, and their perspectives are overlooked at enormous risk to the integrity of our research and teaching. 